\title{
Ю.С. Эзрох
}

Новосибирский государственный университет экономики и управления, Новосибирск

\section{Производственный потенциал современной российской пенитенциарной системы: состояние и меры по развитию}

\begin{abstract}
Аннотация. В статье на основе сплошного анализа официально публикуемых данных в области производственно-хозяйственной деятельности Федеральной службы исполнения наказаний (ФСИН), управлений ФСИН по субъектам федерации и исправительных учреждений впервые в современной России проведено комплексное исследование текущего состояния производственного потенциала уголовно-исполнительной системы (в том числе его производительных сил). Выявлен ряд ключевых макро- и микроэкономических проблем: низкая прозрачность производственно-хозяйственной деятельности ФСИН; недозагрузка имеющихся производственных помещений; отсутствие регламентированного порядка взаимодействия заинтересованных лиц при организации производства; низкий уровень информированности потенциальных бизнес-партнеров о производственных возможностях учреждений ФСИН; недостаточная эффективность экономического управления в исправительных колониях; затрудненность реализации бизнес-инициатив осужденных; недостаточный уровень питания производительных работников, завышенные цены на ряд производимых товаров; затрудненность приобретения продукции розничными покупателями; проблемы позиционирования изготавливаемых товаров. Обоснован стратегический вектор осуществления реформ в области исследования и предложен ряд практических мер по развитию: внедрение периодической публичной отчетности исправительных учреждений по социальным и производственно-хозяйственным аспектам; сплошной аудит имеющихся производственных ресурсов и публичное размещение его результатов; принятие регламента взаимодействия предпринимателей, организовавших производство в исправительных колониях, администрации и осужденных; проведение публичных мероприятий по популяризации совместного производства в учреждениях ФСИН; создание промышленных пенитенциарных парков; содействие реализации бизнес-идей осужденных, активизация сельскохозяйственной работы в исправительных колониях, проведение маркетинговых самообследований; создание единого интернет-магазина ФСИН, проведение централизованных кампаний по продвижению производимой в исправительных колониях продукции.
\end{abstract}

Ключевые слова: экономика уголовно-исполнительной системы, производство ФСИН, труд осужденных, труд заключенных, труд в тюрьме.

Классификация JEL: M19.

Очевидно, что большая масса людей (более 650 тыс. человек на конец 2015 г.), принудительно собранных в пенитенциарной системе, должна как-то участвовать в экономическом воспроизводстве. Әффективно ли это происходит? К тому же государственные расходы на исполнение наказаний огромны - около 270 млрд руб. за 2015 г., т.е. приблизительно $2 \%$ доходов федерального бюджета. За счет чего их можно снизить, частично компенсировать? К сожалению, российские исследователи практически обходят эти вопросы стороной. В 
Электронной научной библиотеке (e-library) находится считанное число научных публикаций в этой области (Антонян, 2011; Матвеева, 2011; Погудин, Чернышов, 2014; Чернышов, 2015) и незначительное число других. Это несопоставимо с масштабом накопленных проблем и противоречий!

При Федеральной службе исполнения наказаний (ФСИН) функционирует комплексный научно-исследовательский институт, в котором есть три центра и два самостоятельных отдела ${ }^{1}$. Однако ни один из них, судя по названиям, не занимается әкономической проблематикой${ }^{2}$. Очевидно, что юридические, педагогико-психологические и медицинские вопросы справедливо являются для ФСИН приоритетными, но экономику ведь никто не отменял! К тому же трудотерапия является одним из важных методов «исправления осужденных и предупреждения совершения новых преступлений как осужденными, так и иными лицами» (Уголовно-исполнительный кодекс, ст. 1) ${ }^{3}$.

В связи с этим вопросы эффективной организации труда заключенных, поиска баланса интересов людей, государства, общества в целом очень важны и незаслуженно отодвинуты в сторону.

О количестве и качестве трудовых ресурсов современной отечественной пенитенциарной системы. В России число лиц, совершающих уголовные преступления, стабильно превышает 1 млн человек в год. Довольно безрадостная картина, учитывая, что людей в возрасте от 15 до 65 лет - 102 млн (т.е. каждый сотый становится уголовником!). Очевидно, что еще существует немалое количество неучтенных по разным причинам уголовных правонарушений. В 20122015 гг. в России ежегодно осуждалось около 730 тыс. человек, причем 40-45\% - это молодые (до 30 лет) люди, каждый десятый из которых несовершеннолетний. Как наказываются преступники? Российский суд чаще всего применяет наказания, не связанные с лишением свободы. Лишь треть виновных в уголовных преступлениях в итоге отправляются за решетку.

Не все люди, которые лишены свободы в стенах учреждений ФСИН, - преступники; существенная часть является подследственными (подозреваемыми или обвиняемыми), т.е. в отношении них выбрана мера пресечения - содержание под стражей сроком до 18 месяцев. Таковых примерно 39 тыс. человек, причем с 2012 г. их число увеличилось на 22\% (при этом общее количество обвинительных решений увеличилось лишь на 2,3\%; это к вопросу гуманности!).

Исправительные учреждения ФСИН состоят из исправительных колоний (колонии-поселения, колонии общего, строгого и особого режимов), воспитательных колоний (для несовершеннолетних ${ }^{4}$ ),

\footnotetext{
${ }^{1}$ НИИ информационных технологий ФСИН - узкоспециализированное учреждение.

${ }^{2}$ Материалы НИИ ФСИН России (http:/ / nii.fsin.su/ob-institute/structura/index.php).

${ }^{3}$ Как отмечается в отчете Управления ФСИН по Владимирской области за 2015 г., «одним из самых эффективных методов обеспечения правопослушного поведения осужденных является их привлечение к оплачиваемому труду».

${ }^{4}$ Число воспитанников - всего 1683 человека (лишь 27 человек находятся повторно). Имеет место существенное сокращение их числа, например, в 2003 г. их число было в десять раз больше - 16491.
} 
тюрем (где режим содержания чрезвычайно строг ${ }^{5}$ ) и лечебных исправительных учреждений (для больных наркоманией, алкоголизмом, открытой формой туберкулеза и др.). Трудовые ресурсы довольно специфичны - большая часть заключенных (144 тыс. человек, т.е. $27,5 \%$ ) являются убийцами, чуть меныше людей отбывают заключение за преступления, связанные с наркотиками, - 134 тыс. человек (25,6\%). Преступников, совершивших кражу, грабеж или разбой, существенно меньше; другие виды преступлений занимают незначительную долю в общей структуре. При этом в последние пять лет доля впервые осужденных стабильно составляла чуть более 1/3 (194 тыс. человек в 2015 г.). Иными словами, основной контингент ФСИН - рецидивисты. Насколько длительно пребывание людей в условиях несвободы? Больше половины заключенных (55\%) осуждены на срок более пяти лет; из них каждый третий совершил особо тяжкое преступление, наказание за которое превышает 10 лет лишения свободы. Это говорит о невысокой «текучести кадров».

Однако не все осужденные могут осуществлять трудовую деятельность. Как отмечал в 2014 г. зам. директора ФСИН О. Коршунов, среди них есть «инвалиды, пенсионеры, женщины с детьми, т.е. те, кто работать не может. Всего в состоянии работать 252 тыс. человек» ${ }^{6}$. Кроме того, среди заключенных значительное число людей с психической патологией $(18,5 \%)$, больных ВИЧ $(8,8 \%)$, туберкулезом $(3,9 \%)$ и другими социально опасными ${ }^{7}$ заболеваниями ${ }^{8}$. Однако это не всегда является противопоказанием к труду, ведь и среди свободных людей далеко не все абсолютно здоровы!

Из вышеизложенного можно сделать ряд важных обобщений. Во-первых, количество уголовных преступлений в России практически не сокращается, что требует от общества адекватного наказания. Во-вторых, число приговоров, связанных с реальным лишением свободы, не имеет тенденции к уменьшению. В-третьих, в местах заключения наряду с убийцами, грабителями и разбойниками много людей, получивших срок за наркотики; очевидно, что их существенная часть представляет опасность прежде всего для себя из-за своей пагубной болезни. Также достаточно много людей, совершивших банальные кражи. В-четвертых, 2/3 обитателей исправительных учреждений являются рецидивистами, надежды на исправление половины которых достаточно невелики (они отбывают третий и более срок). В-пятых, большая часть осужденных приговорена к длительным и очень длительным срокам заключения. В-шестых, не все заключенные могут эффективно работать по объективным причинам, однако доля способных к труду существенна $(\approx 50 \%)$.

\footnotetext{
${ }^{5}$ Используются обычно для злостных нарушителей. Число осужденных - всего 1528 человек на конец 2015 г. Например, известная тюрьма ФКУ Т-2, так называемый Владимирский централ.

${ }^{6}$ Материалы газеты «Коммерсантъ» ( http:/ / www.kommersant.ru/doc/2530596).

${ }^{7}$ Говоря точно, «социально значимыми заболеваниями, представляющими опасность для окружающих» (Постановление Правительства РФ от 1 декабря 2004 г. № 715).

${ }^{8}$ Информация о достигнутых результатах ФСИН (http:/ / fsin.su/budget/info.php).
} 
Странная вещь - закон: посадили за то, что украл буханку хлеба, и теперь приходится выдавать по буханке в день бесплатно ${ }^{9}$. Очевидно, что тюремные стены скрывают много тайн. Однако в отличие, например, от военных предприятий финансово-экономические аспекты деятельности ФСИН должны быть максимально прозрачны. В чем тут тайна? Налогоплательщики, на деньги которых существует эта объективно нужная структура, вправе подробно знать, как именно расходуются немалые средства. В настоящее время в открытом доступе есть лишь сведения о ежегодном финансировании ФСИН без детализации расходов (рис. 1).

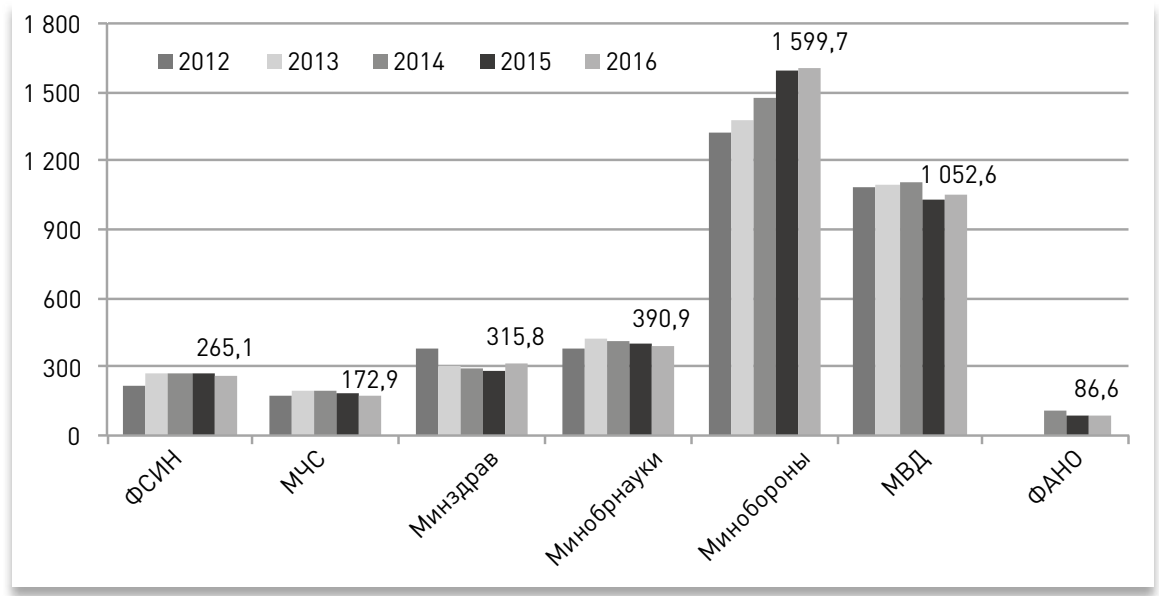

Pис. 1

Государственные расходы (млрд руб.) по отдельным направлениям в 2012-2016 г2.

Источник: бюджетные росписи Минфина России, составлено автором.

Как видно из рис. 1, расходы на исполнение наказаний имеют тенденцию к незначительному снижению (с 271 млрд руб. в 2013 г. до 265 млрд руб. в 2015 г., однако в целом за последние пять лет они увеличились на четверть - более чем на 50 млрд руб.) Объем денежных средств, выделяемых ФСИН, сопоставим с расходами на медицину и образование; при этом они превышают расходы, например, на МЧС и Федеральное агентство научных организаций! Конечно, ряд направлений (например, Минобороны и МВД) требует еще больших государственных затрат. Однако при этом нельзя не отметить, что удельные расходы на одного заключенного очень велики - от 386 до 409 тыс. руб. ежегодно (в 2012-2015 гг. $)^{10}$ !

На основании изложенного можно сделать два ключевых экономических вывода. Во-первых, содержание и поддержание режима среди огромного числа довольно специфического контингента обходится государству достаточно дорого. Во-вторых, в современных кризисных условиях необходимо искать пути снижения расходов налогоплательщиков. Не касаясь вопросов декриминализации ста-

\footnotetext{
9 Современный анекдот.

${ }^{10}$ Реально - несколько меньше. Выделить расходы ФСИН на контроль за теми, кто не лишен свободы (домашний арест, ограничение свободы и т.д.) не позволяет отсутствие соответствующей информации.
} 
тей уголовного кодекса, внедрения технических новинок, сокращающих количество персонала ФСИН, необходимо разобраться, как и насколько эффективно заключенные участвуют в производственном процессе.

«Мы рубим лес, и сталинские щепки, как раньше, во все стороны летят» ${ }^{11}$. Поиск ответа на вопрос, что изготавливают современные российские заключенные, осложняется наличием лишь поверхностной консолидированной информации (рис. 2).

В процентном отношении структура производства в уголовноисполнительной системе в 2015 г. была такова: металлообработкой занималось $15,11 \%$ заключенных, деревообработкой $-10,07 \%$, швейным производством $-22,1 \%$, сельским хозяйством $-12,88 \%$, на остальные виды деятельности приходилось 39,84\%. То есть уголовно-исполнительная система (УИС) в основном развивает легкую промышленность; доля деревообработки, вопреки устойчивым стереотипам, существенно (в 2,2 раза) ниже. Общий объем товарной продукции - 30 млрд руб.; оплачиваемыми работами занято $192,5^{12}$ тыс. человек, т.е. годовая удельная выработка (на одного осужденного) составляет всего $\approx 155$ тыс. руб. (12,9 тыс. руб. в месяц). Иная консолидированная производственно-хозяйственная информация, а также сведения о динамике значений әкономических показателей УИС не раскрывается.

Соответствующие сведения по каждому исправительному учреждению отсутствуют ${ }^{13}$; лишь небольшим числом управлений ФСИН (далее - УФСИН) публикуется консолидированная экономическая информация. Так, во Владимирской, Вологодской и Тверской областях наиболее активно развита легкая промышленность (швейное и обувное производство) - 62, 58 и 40\% соответственно; гораздо меньшую долю занимает производство продуктов питания (хлеба и макаронных изделий) $-12,10$ и $12 \%$.

Насколько публичны данные о производственно-хозяйственной деятельности региональных частей уголовно-исполнительной системы? УФСИН по разным регионам России предоставляют неодинаковую по структуре и наполнению статистическую информацию ${ }^{14}$. Очевидно, что единых требований к публичному раскрытию результатов своей деятельности во ФСИНе нет (либо они не выполняются, что трудно представить в военизированном ведомстве!).

Подавляющее большинство территориальных управлений, например по Астраханской области, по Москве, вовсе не предоставляет статистической информации; отдельные управления, например по Новосибирской области ${ }^{15}$, публикуют весьма поверхностные све-

\footnotetext{
${ }^{11}$ Из стихотворения Юза Алешковского «Простой заключенный» («Товарищ Сталин! Вы большой ученый ...»).

12 По другим данным ФСИН - более 213 тыс. человек, т.е. налицо противоречие!

13 Автор сделал такой вывод на основании сплошного (100\%) анализа публичных сведений УФСИН.

14 Стоит подчеркнуть, что речь идет не только об экономических показателях функционирования УИС.

${ }^{15}$ К тому же текст написан крайне неаккуратно, например, в нем встречаются такие выражения: «ПодразделенияУИС», «Крометого», «продуктыпитания» и т.д.
} 
дения. Фактически лишь $16^{16}$ УФСИН (т.е. каждое пятое управление) раскрывают хоть какие-то консолидированные сведения о результатах своей производственно-хозяйственной деятельности. Это еще больше затрудняет транспарантный анализ. Стоит отметить, что незначительное число управлений предоставляют сведения в достаточно развернутом виде, например УФСИН по Оренбургской области.

Из этого можно предположить, что результаты в экономической области существенной части УФСИН довольно скромные и, вероятнее всего, неоднородные - в ряде колоний наверняка практически отсутствует производство. Иначе зачем скрывать экономические сведения? Кроме того, отсутствие публичности всегда заставляет сомневаться в том, что вся производственно-хозяйственная деятельность, особенно в чрезвычайно закрытых режимных объектах УИС, осуществляется официально.

Исправительная колония или исправительно-трудовое учреждение? Для ответа на этот вопрос необходимо определить, насколько значительная доля заключенных трудоустроена на оплачиваемые работы (рис. 2).

Как видно на рис. 2, доля заключенных, которым предоставлена оплачиваемая работа, весьма невелика - не более $32,8 \%$; обычно меньше - 20-25\%. Стоит отметить, что в спецконтингент включены подозреваемые и обвиняемые ${ }^{17}$, которые содержатся в следственных изоляторах (СИЗО). Это несколько занижает реальные значения, учитывая то, что в СИЗО содержится $18 \% 18$ спецконтингента УИС. Однако данные для точных расчетов (структура заключенных) представлены только некоторыми УФСИН. Как видно на рис. 3, доля

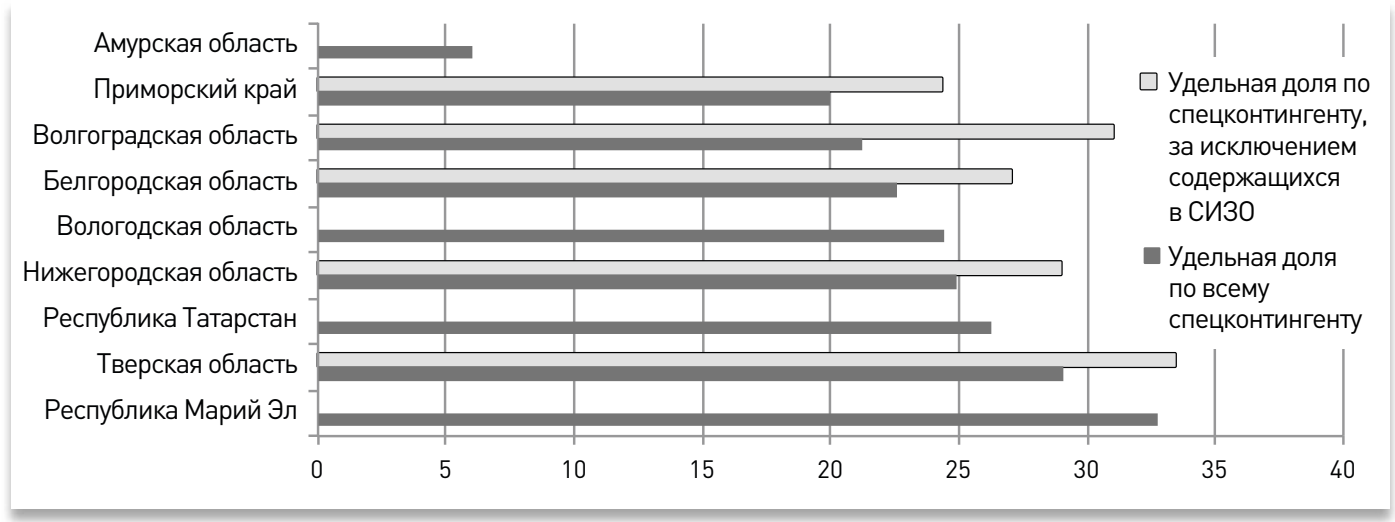

Pис. 2

Доля спеиконтингента УИС, устроенная на оплачиваемые работы в 2015 г., \%

Примечание. Здесь и далее - данные по другим УФСИН для осуществления аналогичных расчетов, сопоставлений отсутствуют.

\footnotetext{
16 По Амурской, Астраханской, Белгородской, Владимирской, Волгоградской, Вологодской, Воронежской, Липецкой, Мурманской, Нижегородской, Оренбургской, Тверской областям, Республикам Марий Эл, Татарстан, Чувашия и Приморскому краю.

${ }^{17}$ Они практически не участвуют в трудовой деятельности по объективным причинам.

18119395 чел. на 01.06.2016 г.
} 
исключительно осужденных, которым предоставлена оплачиваемая работа, несколько выше и составляет от 24,29 до 33,39\%. Иными словами, два из трех человек, лишенных длительное время свободы, не имеют оплачиваемой работы. Официальные консолидированные данные оптимистичнее на 1/3 - в 2014 г. 40\% (двое из пяти) осужденных были выведены на оплачиваемые работы ${ }^{19}{ }^{20}$.

Фактически переименование советских исправительно-трудовых учреждений в просто исправительные колонии было сделано вполне обосновано - современные российские заключенные в основной своей массе не занимаются оплачиваемой работой. Безусловно, труд некоторых осужденных используется для поддержания состояния бараков, общественных мест в колониях, т.е. является априори неоплачиваемым. Однако это не может определять катастрофичные масштабы современной безработицы за решеткой.

Насколько әффективен труд заключенных? Вначале стоит рассмотреть удельный объем товарной продукции, который приходится на одного заключенного, а также совокупный объем реализации товаров учреждениями УИС (рис. 3).

Как видно на рис. 3, в среднем каждый российский заключенный производит продукции на сумму от 10 до 87 тыс. руб. в год, т.е. всего от 0,83 до 7,25 тыс. руб. в месяц! Очевидно, что это несопоставимо с государственными расходами на ФСИН, т.е. государство не имеет никакой прямой ${ }^{21}$ экономической выгоды лишать людей свободы! Можно ли из

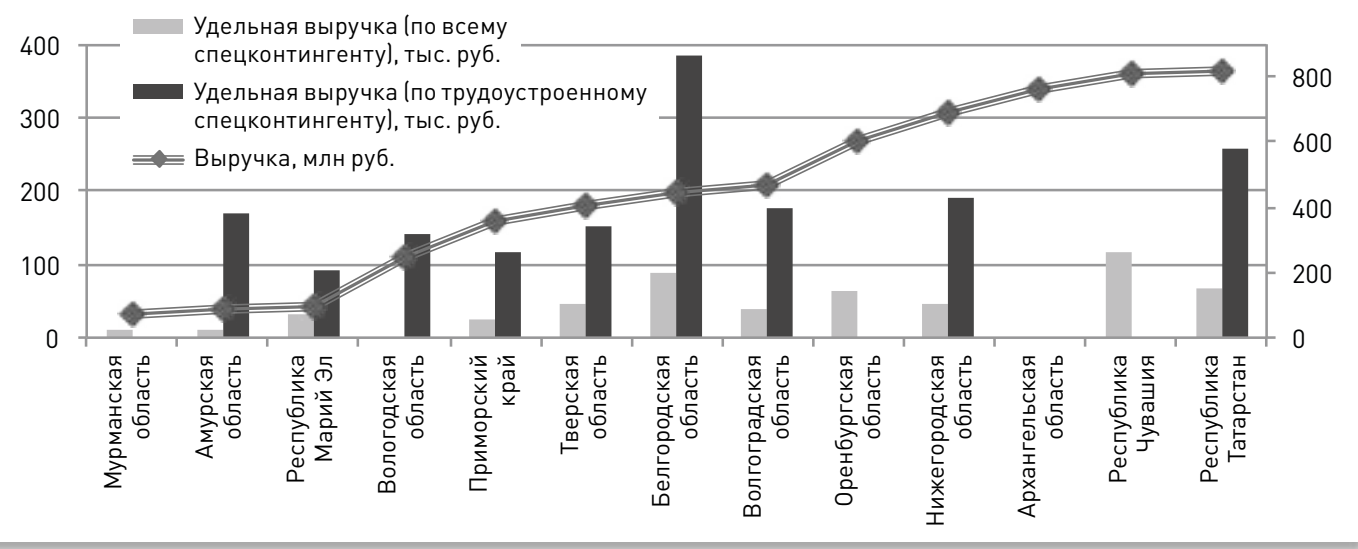

Pис. 3

Сведения о годовой удельной выручке (левая шкала; по спеиконтингенту УИС / по трудоустроенной части) и совокупной годовой выручке по отдельным УФСИН (правая шкала)

Примечание. Сведения представлены преимущественно за весь 2015 г., при наличии сведений за 9 месяцев 2015 г. они приведены к годовому значению.

\footnotetext{
$1937 \%$ - в 2013 г.

20 Доклад о результатах и основных направлениях деятельности ФСИН (http:/ fsin.su/structure/inspector/ iao/Doklad/DROND\%202015-2017.pdf).

21 В исключительно экономическом контексте можно говорить о косвенной выгоде государства. Например, стоимость пожизненного лишения свободы маньяка меньше, чем потери общества от утраты трудоспособных граждан. Хотя, несомненно, общечеловеческий мотив изоляции в данном случае куда важнее. Стоит отметить, что, по некоторым сведениям (официальные отсутствуют), срок дожития в колониях особого режима невелик (3-7 лет). Пожизненно заключенные в России долго не живут ( http://www.online812. $\mathrm{ru} / 2009 / 11 / 24 / 013 /$ pda.html)
} 
этого сделать вывод о непроизводительности труда осужденных? Нет, так как удельная выручка на одного трудоустроенного заключенного существенно выше - от 93 до 386 тыс. руб. (в среднем $\approx 187$ тыс. руб., т.е. 15,5 тыс. руб. на человека). Стоит отметить огромную (до четырех раз!) разницу между производительностью труда в разных УФСИН.

Почему так происходит? Действительно, есть продукция с высокими затратами труда (например, изготовление эксклюзивных резных сувениров), а есть с низкой (например, изготовление железобетона). При равной производительности труда в первом случае стоимость изготовленных товаров будет меньше, чем во втором. Однако, по отдельным сведениям, для улучшения статистики в некоторых колониях привлекают к труду чрезмерное количество заключенных, выплачивая некоторым из них мизерное вознаграждение, которое исчисляется несколькими рублями ${ }^{22}$. Для проверки таких сведений необходимы данные либо о заработке каждого осужденного, либо о значениях показателей вариации (для оценки тесноты значений в выборке). К сожалению, таких сведений в открытом доступе нет.

Однако описанная ситуация не кажется чрезмерно фантастичной.

Насколько велики доходы осужденных? По данным ФСИН, среднедневной заработок работающих осужденных в 2014 г. составил 218,6 руб., т.е. $\approx 5$ тыс. руб. в месяц. Очевидно, что такой уровень дохода для свободных людей крайне невысок. Материальный стимул, являющийся одним из ключевых в обычной жизни, в условиях заключения дополняется рядом других - возможностью разнообразить жизнь и перспективой получить условно-досрочное освобождение. Можно ли на основании этого сделать вывод о том, что современным российским заключенным существенно недоплачивают (рис. 4)?

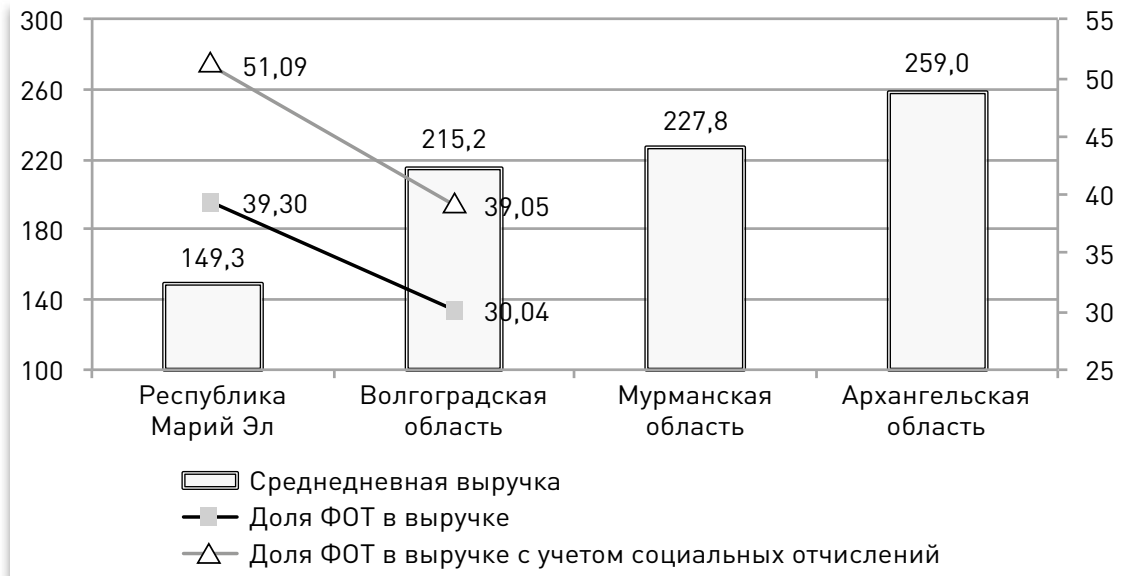

Pис. 4

Сведения о среднедневном доходе трудоустроенных осужденных (левая шкала, руб.) и доле фонда оплаты труда осужденных в выручке (правая шкала, \%) в отдельных УФСИН в 2015 г.

${ }^{22}$ Материалы Сахаровского центра ( http:/ / www.sakharov-center.ru/discussions/?id=1807). 
Как видно на рис. 4, и в 2015 г. уровень дохода заключенных оказался невысок ${ }^{23}$. При этом доля заработной платы в выручке очень высока - с учетом обязательных социальных отчислений она составляет 40-50\%. Такое значение нехарактерно для большинства видов предпринимательской деятельности (обычно не более 15-25\%), за исключением тех, где ключевым активом являются способности сотрудников (ІТ-разработки, налоговое консультирование и т.д.) ${ }^{24}$. Указанное может быть определено тремя группами причин: использованием преимущественно ручного труда, неэффективной организацией труда и искажениями (занижением) в части объема выручки.

Насколько масштабна и эффективна производственнохозяйственная деятельность в исправительных колониях? Как видно на рис. 4, объем произведенных товаров и услуг в учреждениях УИС не слишком велик - лишь в Республиках Татарстан и Чувашия он немного превышает 800 млн руб. в год (819 и 810 млн руб. соответственно). Иными словами, по данному показателю такой «бизнес» мог бы быть отнесен к категории малого (в республиках - среднего)!

Одним из критериев эффективности любой предпринимательской деятельности является абсолютное и относительное значение превышения доходов над расходами (рис. 5).

Как видно на рис. 5, годовая прибыль от хозяйственной деятельности в отдельных УФСИН невелика и составляет 20-40 млн руб. (в среднем 30 млн руб.) Приблизительный подсчет свидетельствует, что величина годовой прибыли УИС может составлять 2-2,5 млрд руб., т.е. не более $1 \%$ расходов на ФСИН. При этом норма прибыли весьма

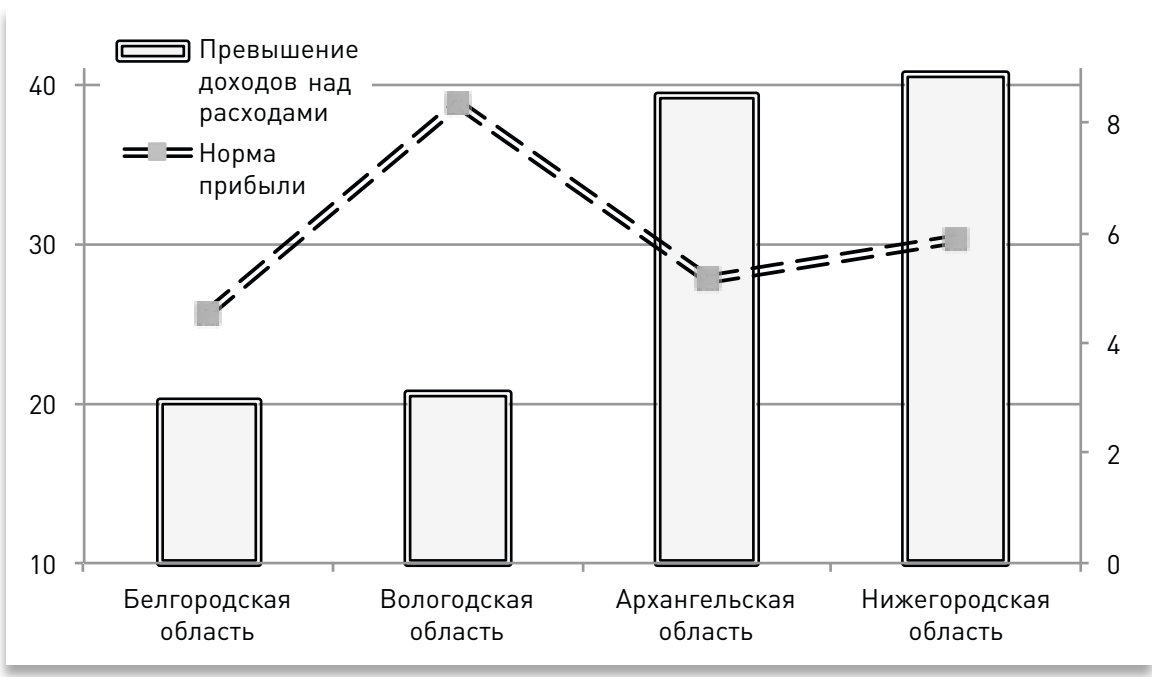

Рис. 5

Сведения о превышении доходов над расходами при производственно-хозяйственной деятельности в отдельньх УФСИН (левая шкала, млн руб.) и расчетной норме при были (правая шкала, \%) в 2015 г.

\footnotetext{
23 Данные ФСИН за предыдущий год, вероятно, несколько завышены.

24 Материалы журнала «Бизнес-Ключъ» (http:/ / www.bkworld.ru/netcat_files/Image/news /fot.jpg).
} 
невелика и составляет не более 5-8\%. Стоит отметить, что она находится практически на минимальном уровне, рекомендованном ФСИН (не менее 5\%). В ряде УФСИН, например по Липецкой области, данный норматив не соблюдается $-3,2 \%$; при этом и уровень среднедневной заработной платы осужденных здесь очень низок - 171,92 руб.

«Голодному человеку можно простить многое, очень многое $»^{25}$. Говоря прямо, современные осужденные явно не жируют - по закону в сутки мужчине полагается не менее 550 г хлеба, 550 г картошки, 250 г овощей, 100 г крупы, 100 г рыбы и 90 г мяса ${ }^{26}$. Нормативы для женщин меньше. Так, в Архангельской области на ежедневное питание одного взрослого осужденного тратили всего 158 руб. Недоедание, безусловно, снижает эффективность труда.

В поисках резервов. Учитывая то, что уровень «безработицы» в исправительных колониях значителен, а коммерческая әффективность находится на невысоком уровне, возникает вопрос, каким образом можно обеспечить дополнительную экономически целесообразную деятельность заключенных в настоящее время. По понятным причинам производственные цеха должны быть только на территориях колоний. Есть ли еще свободные площади?

Сайты сорока, т.е. половины, всех УФСИН содержат сведения о характеристиках помещений, которые колонии готовы предоставить для организации совместных производств ${ }^{27}$. Например, УФСИН по Тульской области сообщает, что «имеющиеся мощности загружены в среднем на $40 \%$. <..> все свободные производственные площади $(20$ тыс. м²) оснащены инженерными коммуникациями и технологическим оборудованием». В большинстве случаев сообщается о низкой арендной плате, а УФСИН по Смоленской области готово предоставить помещения и вовсе безвозмездно.

Площади помещений, предлагаемые исправительными колониями для организации производства на 01 июля 2016 г. $\left(\right.$ м² $\left.^{2}\right)$ общая площадь - 561410 ; площадь в одной колонии максимальная - 40000 (минимальная - 50); средняя площадь по всем УФСИН - 14035 ; средняя площадь по всем УФСИН без экстремальных значений - 8004 . Ряд колоний декларирует наличие чрезвычайно (экстремально) больших площадей, например, в 78 тыс. м² в Калмыкии. Вероятно, речь идет о сельскохозяйственных постройках, открытых складах, а не о производственных зданиях, ангарах и т.д.

Как видно из приведенных данных, в настоящее время в колониях не используются помещения площадью более 560 тыс. м². Это очень много! Для сравнения: площадь цехов и административных зданий завода Вoeing ${ }^{28}-400$ тыс. м², а самой большой фабрики в мире (Уралвагонзавода) -827 тыс. м².

\footnotetext{
25 В. Шаламов, из цикла «Колымские рассказы».

${ }^{26}$ А также ряд других продуктов в незначительном объеме, например 30 г макарон, 1 г чая. (Постановление Правительства РФ № 205 от 11 апреля 2005 г.).

27

При перечислении характеристик таких помещений нередко указывается очевидное - «расположено на охраняемой территории».

${ }^{28}$ Самые большие заводы мира (http:/ / www.uznayvse.ru/interesting-facts/samyie-bolshie-zavodyi-v-mire.html).
} 
Насколько свободные помещения в исправительных колониях пригодны для немедленного использования (как это обычно декларируется $\left.{ }^{29}\right)$ ? К сожалению, их фотографии, подтверждающие пригодное состояние, размещены только двумя УФСИН (по Кировской и Тюменской областям). Почему остальные не показывают свой товар лицом потенциальным бизнесменам?

Вопрос организации нового производства в небольших городах и поселках априори сложнее, чем в крупных городах. Однако существенная часть незадействованных помещений $(155,0$ тыс. м²) находится в колониях, расположенных в крупных городах - столицах регионов. Это составляет $27,6 \%$ общего числа незадействованных помещений; если исключить сведения о четырех УФСИН ${ }^{30}$, декларирующих наличие чрезвычайно большого количества свободных площадей (более 50 тыс. м²), то доля свободных городских помещений в уголовно-исполнительной системе увеличится до 53,8\%. Проще говоря, каждое второе помещение расположено в крупном городе, т.е. в месте с хорошей транспортной доступностью (для доставки сырья и отгрузки готовой продукции). Например, свободные площади в УФСИН по Волгоградской области -26,7 тыс. м², по Астраханской области - 12,5 тыс. м².

Ряд УФСИН и исправительных учреждений предоставляют список имеющегося оборудовании (без указания года выпуска, степени износа и т.д.). Это, к сожалению, не позволяет понять реального положения дел, так как неясно, в каком состоянии оно находится (вполне возможно, это просто металлолом).

О действующей системе реализации товаров. В феврале 2014 г. ФСИН анонсировало создание специализированного торгового дома, «который займется продажей изделий заключенных - от ножей и нардов до сборных жилых домов» ${ }^{31}$. К числу существующих проблем было отнесено то, что «ФСИН пока не умеет рекламировать собственную продукцию, и о ней мало кто знает» ${ }^{32}$. В настоящее время сведения о реальной деятельности ФГУП «Производственно-промышленный дом» отсутствуют; сайт, указанный на официальном портале ФСИН $^{33}$, не функционирует. При этом в настоящее время проблема с реализацией стоит очень остро!

Так, автор предпринял попытку приобрести сувенир - резной корабль в исправительной колонии № 1 УФСИН по Карельской области. По электронной почте был задан ряд уточняющих вопросов. Ответ, который пришел достаточно быстро, был лаконичен: «Добрый день. Стоимость кораблей от 4500 до 15000 руб. Доставки у нас нет». Стоит отметить, что сама колония находится в поселке городского типа Надвоицы, расположенном в Сегежском районе Карелии

\footnotetext{
29 Лишь УФСИН по Калининградской области указало на аварийное состояние ряда помещений.

${ }^{30}$ По Республикам Калмыкия и Мордовия, по Владимирской и Волгоградской областям.

${ }^{31}$ Материалы ФСИН (http:/ / fsin.su/news/index.php?ELEMENT_ID=121697\&sphrase_id=914680).

${ }^{32}$ Сидеть и работать по-капиталистически (https:/ / www.gazeta.ru/social/2013/06/27/5396673.shtml).

${ }^{33}$ http://www.ppd-fsin.ru.
} 
в 280 км от региональной столицы - Петрозаводска. Неужели отдел маркетинга исправительной колонии действительно рассчитывает, что розничные покупатели (особенно клиенты из других регионов) могут поехать в такую даль?

Электронные адреса ряда колоний, указанные на официальном сайте ФСИН как контакты для заказа изделий, не работали ${ }^{34}$. Существенная часть колоний вопрос о приобретении их товаров и вовсе проигнорировала ${ }^{35}$. К тому же раздел для поиска товаров ${ }^{36}$, изготавливаемых в УИС, корректно не функционировал (найти нужный товар объективно непросто).

Можно ли таким образом вести успешную производственнохозяйственную деятельность? Никоим образом! Безусловно, это частные случаи, однако они могут характеризовать состояние всей системы реализации товаров ФСИН в настоящее время.

Каковы стратегические цель и задачи развития производственного потенциала отечественной пенитенциарной системы? В отдельные периоды истории в России труд заключенных был реальным источником развития экономики (строительство каналов, ГЭС и т.д.). В настоящее время очевидно, что при соблюдении гуманных условий труда (а это безусловный принцип) коммерческая эффективность добровольного труда заключенных в целом по УИС будет отрицательной. Это доказывается тем, что труд одного заключенного не может приносить 400 тыс. руб. (удельные расходы ФСИН) чистой прибыли за год (реальное значение примерно в 100 раз меныше). В таком случае ключевыми стратегическими задачами развития производственного потенциала пенитенциарной системы должны быть:

1) создание условий для всех(!) желающих осужденных выполнять оплачиваемую работу;

2) обеспечение оплачиваемой работой на полную ставку, т.е. 40 часов в неделю (если производство не является вредным), с возможностью трудоустройства по совместительству (не более чем на 0,5 ставки);

3) создание приемлемых санитарно-гигиенических условий труда;

4) обеспечение возможности получения заработной платы не ниже прожиточного минимума (на 1 июля 2016 г. - 7500 руб.) ${ }^{37}$;

5) проведение и использование на практике фундаментальных и прикладных научных исследований в области пенитенциарной экономики ${ }^{38}$.

Стоит отметить, что задачи, указанные в пп. 1-2, не отражены в «Концепции развития уголовно-исполнительной системы

\footnotetext{
${ }^{34}$ На момент написания статьи. Например, ИК-9 в Республике Коми, ИК-4 в Саратовской области.

${ }^{35}$ Например, ИК-1, ИК-22 в Республике Коми.

${ }^{36}$ http:/ / fsin.su/product.

${ }^{37}$ К тому же многие осужденные обязаны выплатить компенсацию потерпевшим, штраф государству и т.д.

38 За последние 6 лет (с 2010 г.) была защищена единственная диссертация (кандидатская) в данной области (в 2013 г. Е.П. Радченко). Возможно, их число больше за счет тех, которые имеют гриф «ДСП» (для служебного пользования). Насколько обоснована секретность материалов?
} 
Российской Федерации до 2020 г.», а указанные в п. 5 описаны лишь обобщенно. Это серьезное упущение, не позволяющее достичь ключевой, по мнению автора, цели развития производственного потенциала отечественной пенитенциарной системы на современном этапе - исправление и адаптация к новой жизни осужденных путем осуществления осмысленной, целесообразной и приемлемо оплачиваемой трудовой деятельности с соблюдением всех трудовых прав.

Вывод о состоянии производственного потенциала отечественной пенитенциарной системы и ключевые проблемы, мешающие его реализации. Современное производство за колючей проволокой является коммерчески малоэффективным и не способным полностью достичь цель и выполнить задачи, указанные выше. В связи с этим и в 2016 г. можно полностью согласиться (в экономическом аспекте) с тем, что было отмечено в 2010 г. в «Концепции...» - «уголовно-исполнительная система во многом сохранила черты старой пенитенциарной системы, ориентированной на другое общество. Она не учитывает нынешнее состояние экономики...». Это требует серьезной модернизации, которая должна решить основные проблемы.

1. Низкая прозрачность производственно-хозяйственной деятельности ФСИН. Учреждения уголовно-исполнительной системы априори закрытые режимные объекты. Однако что секретного в социально-экономических аспектах деятельности ФСИН? Ничего! Любые тайны приводят к неэффективности, бесконтрольности и, как следствие, ущемлению прав осужденных, которые уже и так лишены свободы.

Предложение (адресат - Министерство юстииии РФ, в ведении которого находится ФСИН). Необходимо разработать и внедрить подробную форму периодического (ежемесячного или квартального) публичного отчета каждого исправительного учреждения по социальным и производственно-хозяйственным аспектам. Это позволит понять, какие колонии являются отстающими, а также разобраться в причинах этого. Разве общество, которое наказывает преступников и финансирует уголовно-исполнительную систему, не вправе это знать?

2. Большое число помещений в колониях не используется. Достоверная информация о том, что они собой представляют, в каком состоянии находятся, отсутствует; также вызывает вопрос актуальность публикуемых сведений.

Предложение (адресат - ФСИН). В данной области необходим сплошной аудит; его результаты (планы помещений / подъездов к ним, исчерпывающие технические характеристики, качественные фотографии) должны быть выложены в открытый доступ для потенциальных бизнес-партнеров (предпринимателей).

3. Нет ясного порядка дальнейшего взаимодействия заинтересованных лиц при организации производства. Очевидно, что без госу- 
дарственно-частного партнерства невозможно развивать экономику пенитенциарной системы ${ }^{39}$. При этом любой бизнесмен справедливо опасается вкладывать деньги в не до конца понятные проекты.

Предложение (адресатъ - Министерство экономического развития РФ и Министерство юстииии РФ совместно). Единый (федеральный) регламент взаимодействия предпринимателей, организовавших производство в колонии, администрации и заключенных должен быть составлен предельно четко, не допуская двойных толкований, и опубликован в открытых источниках.

4. Уровень информированности потенциальных бизнес-партнеров о производственных возможностях УИС невысок. Сайты УФСИН содержат разного рода предложения: от сдержанных - «готовы рассмотреть Ваши предложения» (во Владимирской области) до доброжелательных - «окажем максимальное содействие» (в Курганской области). Однако этого недостаточно!

Предложение (адресаты - региональные управления ФСИН и министерства экономического развития суббектов федерачии совместно). Необходимо периодическое проведение максимально публичных «Дней открытых дверей для бизнеса», освещаемых прессой; поддержка их на уровне первых лиц управления ФСИН. Очевидно, что многие захотят узнать больше, а дальше - «реклама - двигатель торговли». Для некоторых, в том числе студентов, это может быть первый опыт занятия своим бизнесом, так как ряд вопросов уже решен (штат легко набрать / уволить, помещения готовы и т.д.).

5. Количество свободных площадей в колониях, расположенных в региональных столицах, достаточно существенно. Имеющиеся помещения фактически расположены на наиболее экономически развитых территориях; их недозагрузка свидетельствует о неэффективности экономического управления.

Предложение (адресатъ - региональные управления ФСИН и министерства экономического развития субъектов федераиии совместно). Создание промышленных пенитенциарных парков, т.е. приведение имеющихся помещений в надлежащий производственный вид (создание проектов зонирования площадей, подведение и разводка электро-, теплоэнергии, водоснабжения и канализации, косметический ремонт и т.д.), формирование и продвижение коммерческих предложений по занятию площадей. Ключевыми принципами должны быть: низкая стоимость арендной платы и полное содействие развитию (при безусловном поддержании режима на территории колонии). Это должно сопровождаться введением прозрачной и эффективной системы финансовой мотивации сотрудников ФСИН, реализующих программу.

6. В настоящее время инициативы внешних бизнесменов недостаточно, а бизнес-инициативы осужденных объективно трудно реализовать из-за режимных ограничений.

39 Лишь некоторые аспекты данной проблемы освещены в следующих трудах -(Ибрагимов, 2015; Козин, Коршунов, 2015; Радченко, 2013; Светлаков, Фазлиев, 2015). 
Предложение (адресат - ФСИН). Оказать содействие реализации бизнес-идей осужденных (среди которых немало инициативных людей, а также профессиональных бизнесменов), направленных на организацию производства внутри колонии. Для этого разрешить использование ими средств телефонной и Интернет-связи, а также проведение прямых переговоров с партнерами (при условии примерного поведения и согласия режимного отдела колонии).

7. Для әффективной работы люди должны хорошо питаться. Текущий рацион российских заключенных явно не способствует высокой производительности.

Предложение (адресать - ФСИН, региональные управления $\Phi С И Н)$. Активизация сельскохозяйственной работы в колониях. Выращивание кур, свиней, а особенно кроликов, разведение рыбы и т.д. - не такая сложная работа. Под руководством бригады профессиональных зоотехников заключенные могут быстро и в больших количествах создать поголовье животных, которым не нужно много места (что может быть актуально для ряда колоний). Это позволит повысить показатели коммерческой эффективности и занятость, а также улучшить здоровье осужденных (часть продукции должна быть предоставлена трудящимся колонии).

8. Цены на ряд товаров, изготавливаемых колониями, выше рыночных.

Предложение (адресаты - ФСИН, региональные управления $\Phi С И Н)$. Провести маркетинговые самообследования, определить конкурентоспособность своей продукции и, при необходимости, скорректировать ценовую политику.

9. Приобретение товаров розничными покупателями крайне затруднено; на Колыму за понравившимся банным ковшом никто не поедет.

Предложение (адресат - ФСИН). Создать единый Интернетмагазин ФСИН с современным интерфейсом и возможностью безналичной оплаты. Организация доставки даже из самых дальних колоний может осуществляться «Почтой России» ${ }^{40}$; при желании можно организовать отправку из колонии до административного центра, а оттуда - любой транспортной компанией. Основная цель - сделать возможным покупку товаров, изготовленных в колониях, без всяких проблем.

10. Колонии обычно выпускают свою продукцию без торговой марки, как бы стесняясь ее происхождения.

Предложение (адресаты - ФСИН). Общеизвестно, что марочные товары продаются лучше, особенно если эта марка с историей. Как это сейчас принято, стоит провести всенародное голосование (которое само по себе является рекламной кампанией) по выбору национальной марки, например, «Сделано ЗК» или «Магаданский привет». Это позволит повысить узнаваемость и, соответственно, продажи ${ }^{41}$.

${ }^{40}$ Небыстро, но, говоря объективно, посылки теряются крайне редко.

41 Классических маркетинговых ходов очень много: «С каждых 100 рублей 1 рубль перечисляется на борьбу с наркоманией», «При покупке трех табуретов - четвертый в подарок» и т.д. Важно запустить Интернет торговлю, привычную потребителям. 
Заключение. Вопросы, поднятые в данной статье, являются сложными, во многом противоречивыми. На первый взгляд может показаться, что они далеки от привычной жизни большинства россиян. Это не так! Огромное количество людей, отбыв назначенное наказание, должны вернуться в общество, сделав верные выводы. Этому способствует возможность всех желающих осужденных получить профессию, заняться нормальным трудом и реализовать свои способности. В настоящее время условия для этого в УИС созданы в недостаточной мере.

Настоящая статья не смогла ответить на все накопленные десятилетиями промышленные вопросы, однако показать реальное (и не слишком хорошее) состояние производственного потенциала российской пенитенциарной системы, заострить внимание на некоторых экономических проблемах, обосновать ряд дискуссионных мер по развитию, пожалуй, смогла. И главное, она призывает начать комплексное ускоренное развитие экономического потенциала российской пенитенциарной системы.

\section{ЛИТЕРАТУРА}

Антонян Е.А. (2011). Проблемы развития производственного потенциала уголовно-исполнительной системы Российской Федерации // Вестник Волгоградской академии МВД России. № 4. С. 57-61.

Ибрагимов О.А. (2015). К вопросу о развитии системы унитарных предприятий уголовно-исполнительной системы в новейшей истории России / / Уголовно-исполнительное право. № 2. С. 99-104.

Козин М.Н., Коршунов О.А. (2015). Государственно-частное партнерство как драйвер развития экономики пенитенциарной системы. В сб.: «Труды Международной научно-практической конферениии спещиалистов, ученых, аспирантов». С. 230-238.

Матвеева Н.С. (2011). Ресурсный потенциал производственного сектора уголовно-исполнительной системы России // Вестник института: преступление, наказание, исправление. № 2. С. 64-72.

Погудин О., Чернышов И. (2014). Производственный потенциал уголовноисполнительной системы России: на пути к возрождению или к стагнации? // Проблемы теории и практики управления. № 2. С. 132-139.

Радченко Е.П. (2013). Социально-экономические предпосылки формирования государственно-частного партнерства в российской пенитенциарной системе // Известия Иркутской государственной экономической академии. № 3. С. $110-112$.

Светлаков А.Г., Фазлиев И.Н. (2015). Современный инструментарий повышения экономической эффективности деятельности подсобных хозяйств в специальных учреждениях системы ФСИН / / Аграрный вестник Урала. № 7. С. $95-100$.

Чернышов И.Н. (2015). Эволюция принудительного труда: от истории к современности // ЭКО. № 3. С. 167-177.

Поступила в редакиию 18 июля 2016 года 
REFERENCES (with English translation or transliteration)

Antonyan E.A. (2011). Productive Potential Development Problems of the Russian Federation Penal-Executive System. Bulletin of the Volgograd Academy of the Ministry of Internal Affairs of Russia, 4, 57-61 (in Russian).

Chernishov I. (2015). The Evolution of Coercive Labor: from History to Modernity. ECO, 3, 167-177 (in Russian).

Ibragimov O.A. (2015). On the Development of the System of Unitary Enterprises of the Criminal-Executive System in the Recent History of Russia. Penal Law, 2, 99-104 (in Russian).

Kozin M.N., Korshunov O.A. (2015). Public-Private Partnership as a Driver of Economic Development of the Penitentiary System. In: "Proceedings of the International Scientific and Practical Conference of Specialists, Scientists, PhD Students", 230-238 (in Russian).

Matveeva N.S. (2011). The Resource Potential of Industrial Sector of the Penal System of Russia. Herald of the Institute: crime, punishment, correction, 2, 64-72 (in Russian).

Pogudin O., Chernishov I. (2014). The Production Potential of Russian Penal Enforcement System: on the Way to Renewal or to Stagnation? The International Journal Theoretical and Practical Aspects of Management, 2, 132-139 (in Russian).

Radchenko E.P. (2013). Socioeconomic Preconditions for Creation of Public-Private Partnerships in the Russian Penitentiary System. The Bulletin of Baikal State University, 3, 110-112 (in Russian).

Svetlakov A. G., Fazliev I.N. (2015). Modern Tools to Increase the Economic Efficiency of the Activities of Farms in Special Agencies of the Federal Penitentiary Service. Agrarian Bulletin of the Urals, 7, 95-100 (in Russian).

Received 18.07.2016

\section{Y.S. Ezrokh}

Novosibirsk State University of Economics and Management, Novosibirsk, Russia

\section{The Production Potential of the Modern Russian Penitentiary System: The State and Development Measures}

\footnotetext{
Abstract. In the article, based on a continuous analysis of officially published data on production and economic activities of the Federal Penitentiary Service (FSIN), FSIN directorates for the subjects of the federation and correctional institutions, a comprehensive study of the current state of the production potential of the penitentiary system including its productive forces has been conducted. A number of key macro- and microeconomic problems were identified: low transparency of production and economic activities of the FSIN; underloading of existing production facilities; A low level of information for potential business partners about the production capabilities of the FSIN institutions; insufficient effectiveness of economic management in correctional colonies; difficulty in implementing business initiatives of convicts; insufficient level of nutrition of productive workers. A number of practi-
} 
cal measures for development of production potential are proposed: introduction of periodic public reporting of correctional facilities on social and production aspects of their activity; continuous audit of available production resources and public distribution of its results; adoption of regulations for cooperation between entrepreneurs who organized production in correctional colonies, administration and convicts; creation of industrial penitentiary parks; assistance in realization of business ideas of convicts, activation of agricultural work in correctional colonies, conducting of marketing self-examination; the creation of a single online store of the Federal Penitentiary Service, the holding of centralized campaigns to promote products produced in correctional colonies.

Keywords: economics of the penal system, penitentiary, convicts' labour, prison labour, work in prison.

JEL Classification: M19. 